\title{
Evaluation of biological activities of raw and cooked Brassica oleracea sprout extracts rich in bioactive compound Sulforaphane
}

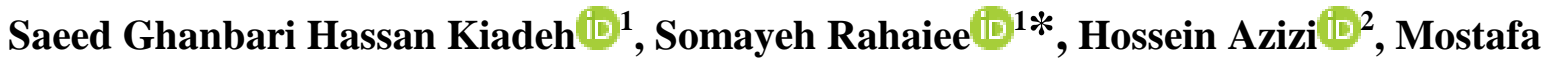 \\ Govahi iD 2
}

\begin{abstract}
Background and Aims: Broccoli sprout extract (Brassica oleracea) has extensive biological activities that are mainly attributed to the presence of bioactive compounds, such as sulforaphane. This study aimed to investigate the antioxidant and antibacterial activities of cooked and raw extracts of broccoli sprouts.
\end{abstract}

Materials and Methods: The amount of sulforaphane in broccoli sprout extract was evaluated by highperformance liquid chromatography (HPLC). Moreover, the amount of phenolic and flavonoid compounds and antioxidant capacity were investigated by the DPPH free radical scavenging method. In addition, the antibacterial activity of raw and cooked sprout extracts on some bacteria was explored using disk diffusion assay and minimum inhibitory concentration (MIC) by macro dilution method. Significant differences were analyzed by one-way analysis of variance (ANOVA) through Duncan's multiple range test.

Results: Based on the results obtained by HPLC, the amount of sulforaphane in the raw broccoli sprout extract was determined to be $787.46 \mu \mathrm{g} / \mathrm{mL}$. Moreover, the antioxidant activity of raw and cooked sprout extracts depicted a higher antioxidant activity with an increase in concentration. Furthermore, the antibacterial study showed that cooked sprout extract had higher antimicrobial activity, compared to the raw sprout extract (at a significance level of 0.05). The highest growth inhibition zone was found against Grampositive Bacillus cereus strain with a diameter of $18 \pm 0.6 \mathrm{~mm}$; moreover, the lowest amounts of MIC and MBC were obtained at 0.39 and $0.78 \mathrm{mg} / \mathrm{mL}$, respectively.

Conclusion: In general, the results show that cooked broccoli sprout extract has significant antioxidant and antibacterial activities, compared to the raw sprout. Accordingly, it can be utilized in food, health, and medical products as a highly promising source. However, further studies are required to be conducted in this regard.

Keywords: Antibacterial activity, Antioxidant activity, Bioactive compounds, Broccoli sprout extract, Sulforaphane

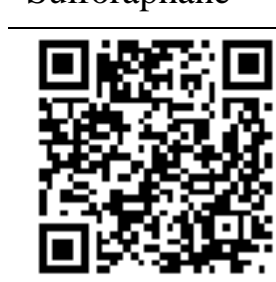

Citation: Ghanbari Hassan Kiadeh S, Rahaiee S, Azizi H, Govahi M. [Evaluation of biological activities of raw and cooked Brassica oleracea sprout extracts rich in bioactive compound Sulforaphane]. J Birjand Univ Med Sci. 2021; 28(3): 236-247. [Persian]

DOI http://doi.org/10.32592/JBirjandUnivMedSci.2021.28.3.102

Received: June 20, 2021

Accepted: September 11, 2021

\footnotetext{
${ }^{1}$ Department of Microbial Biotechnology, Faculty of Biotechnology, Amol University of Special Modern Technologies, Amol, Iran

2 Department of Nano Biotechnology, Faculty of Biotechnology, Amol University of Special Modern Technologies, Amol, Iran

* Corresponding author: Department of Microbial Biotechnology, Faculty of Biotechnology, Amol University of Special Modern Technologies, Amol, Iran
}

Tel: +989118675234

Fax: +9811-44154265

E-mail: S.rahaiee@ausmt.ac.ir

236 


\section{بررسى فَّاليتهاى بيولوزيكى عصار ههاى جوانه خام و يخته كلم بروكلى (Brassica oleracea) غنى از تركيب زيست فعال سولفور افان}

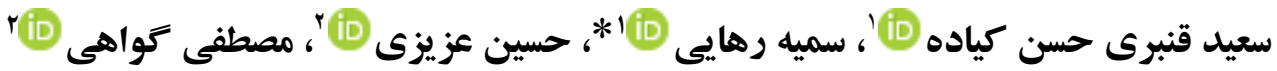

\section{جكکبه}

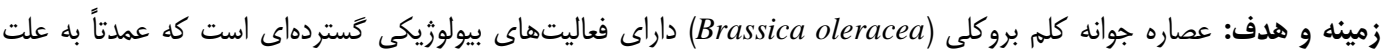

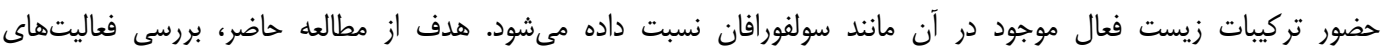

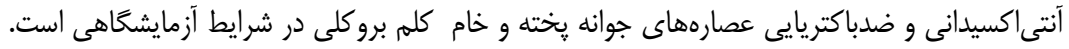

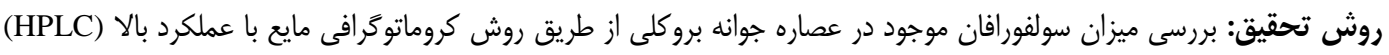

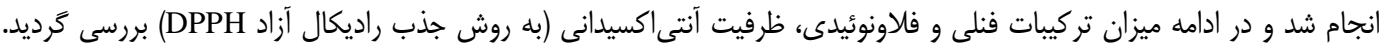

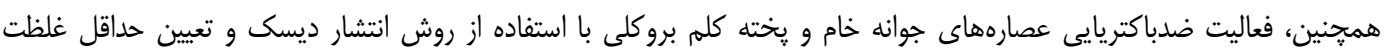

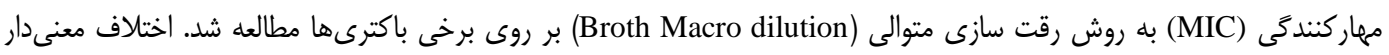

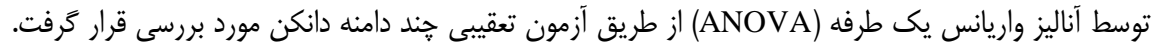

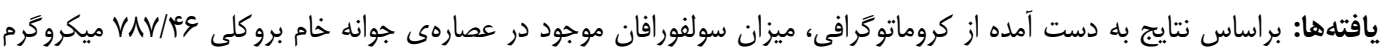

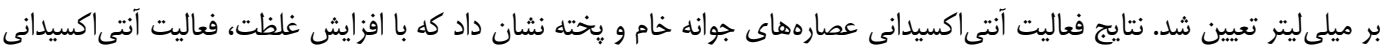

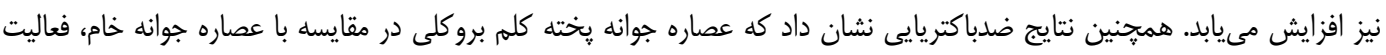

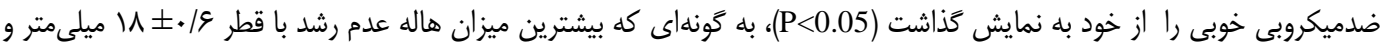

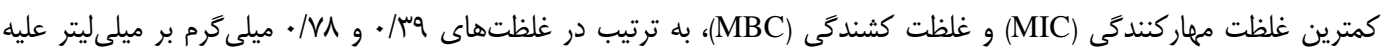

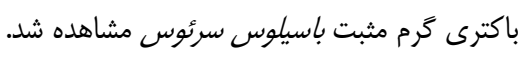

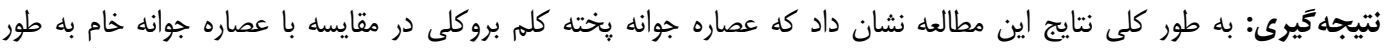

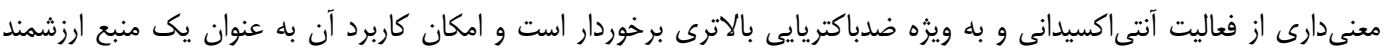

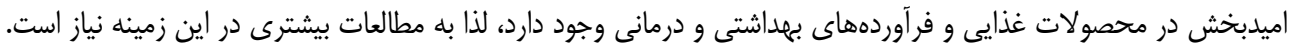
وازههاى كليدى: فتّاليت ضدباكتريايى، فغّاليت آنتىاكسيدانى، تركيبات زيست فعال، عصاره جوانه كلم بروكلى، سولفورافان

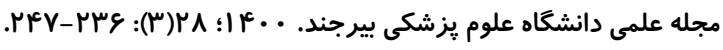

$$
\text { دريافت: • | }
$$

' "كروه زيست فناورى ميكروبى، دانشكده زيست فناورى، دانشخاه تخصصى فناورى هاى نوين آمل، آمل، ايران

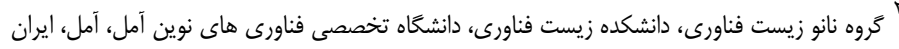

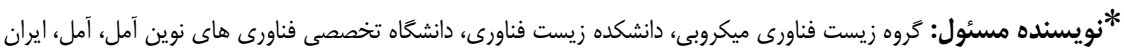

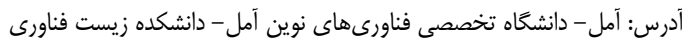

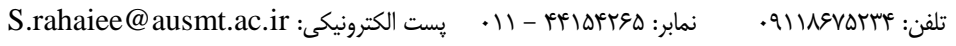


كه عصاره خام اثرات ضدميكروبى جشمخيرى را از خود به نمايش

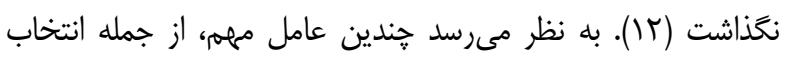

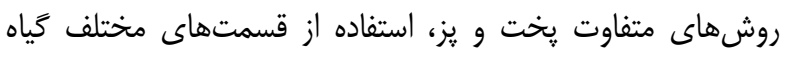

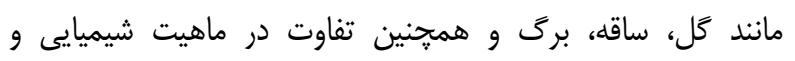
روشهاى بررسى، به طور قابل توجهى بر فعاليت ضدميكروبى و

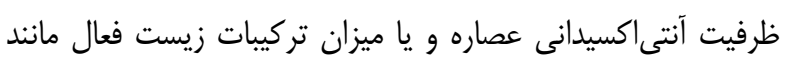

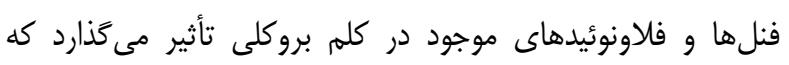
مىتواند منجر به كاهش، ثبات و يا افزايش ميزان آنها شود. در

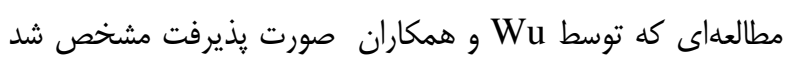

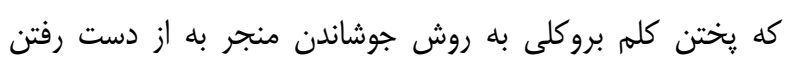

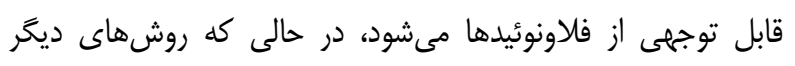

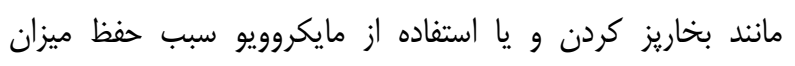
فلاونوييدها و حتى افزايش ميزان آزادسازى آنها در عصاره مى مَردد

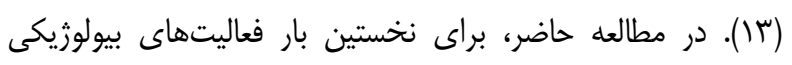

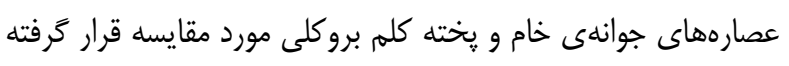
است. هدف از مطالعه حاضر، بررسى تركيبات زيست فعال موجود در

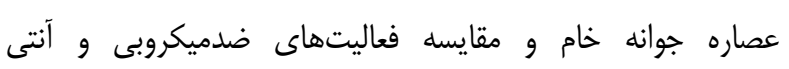
اكسيدانى آن با عصارهى جوانه يخته شده كلم بروكلى مى باشد.

\section{روش تحقيق}

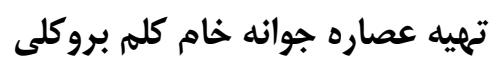

بذرهاى كلم بروكلى از مركز جهاد كشاورزى استان مازندران تهيه شد. جهت تهيه جوانه كلم بروكلى، ابتدا بذرهاى كلم بروكلى به

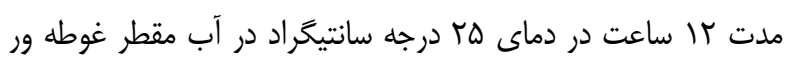
شدند و سبيس به صورت وارونه در شرايط تاريكى قرار كرفتند. در مرحله بعد جوانههاى رشد يافته توسط دستخاه خشى كن انجمادى

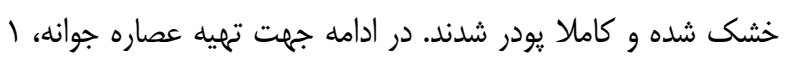

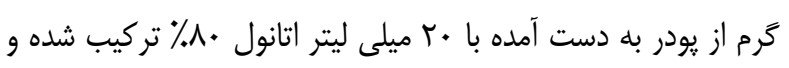

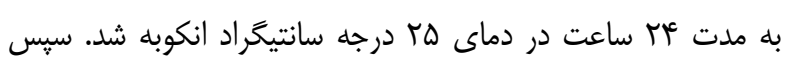

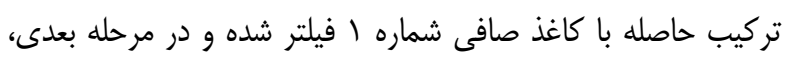

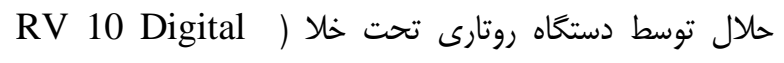

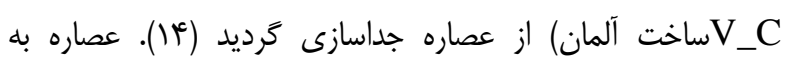

\section{مقاله}

سبزيجات حلييائى متعلق به خانواده Brassicaceae و شامل سبزيجاتى مانند كل كلم، كلم و كلم بروكلى ( Brassica

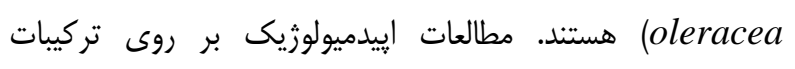
شيميايى حاصل از عصاره جوانههاى كلم بروكلى طيف گسترداى از

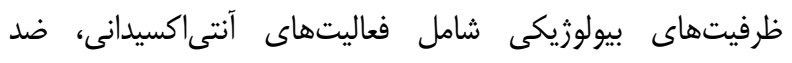

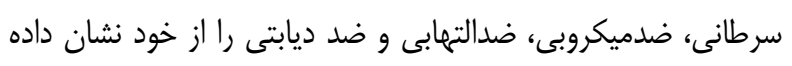

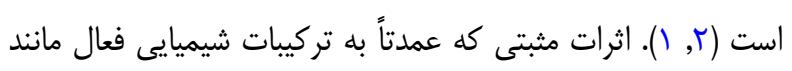

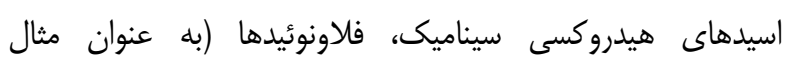

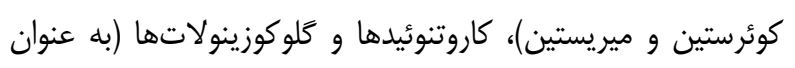

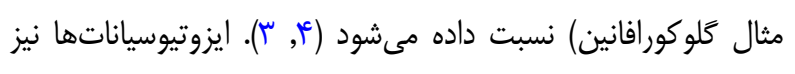
در واقع اشكال فعال كلوكوزينولاتها هستند كه در رأس آنها تركيب زيستى فعالى به نام سولفورافان قرار دارد كه با عملكرد آنزيم

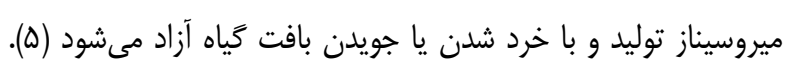
در سالهاى اخير، بذر و به خصوص جوانههاى كلم بروكلى به دليل

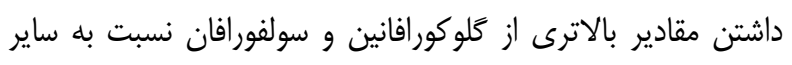

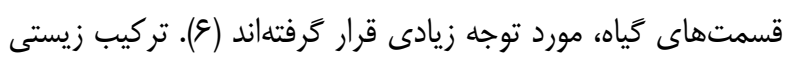

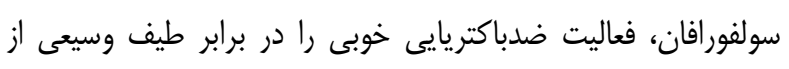

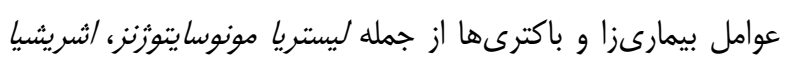

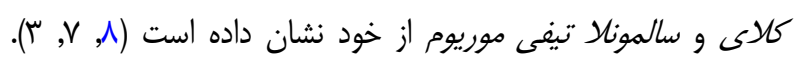
همجنين كزارشات اخير حاكى از آن است كه كلم بروكلى به علّ الت

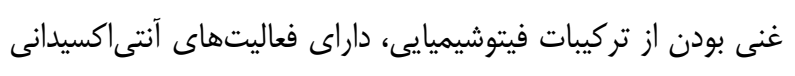

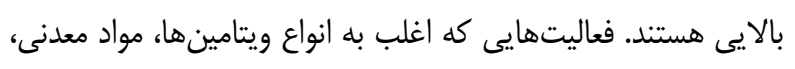

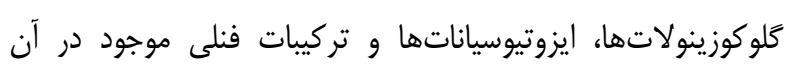
نسبت داده مىشود (1) (1) • (1, 9).

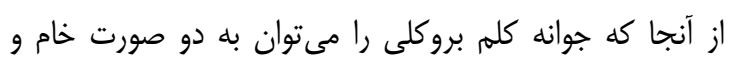

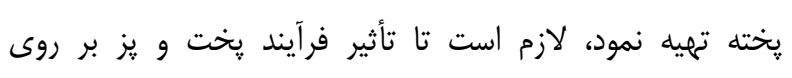
تركيبات فعال موجود در قسمتهاى مختلف آن مورد بررسى قرار كيرد، فرآيندهايى كه مىتواند منجر به تغيير در فعاليت تركيبات

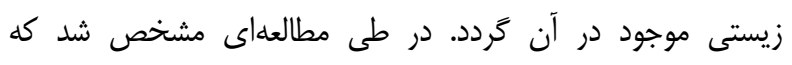

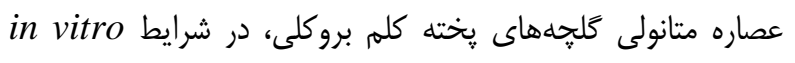

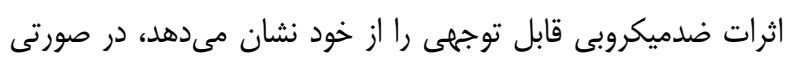


اندازهَيرى محتواى فنل و فلاونوئيد كل عصارههاى

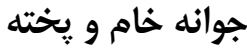

جهت تعيين ميزان فلاونوئيد عصارههاى جوانه خام و ڤخته

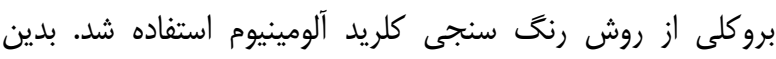

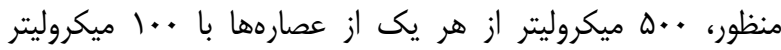

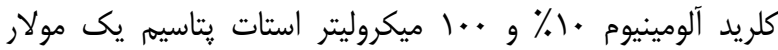
تركيب و در ادامه به آن جهار هزار و سيصد ميكروليتر اتانول •ــ٪ اضافه شد تا به حجم نهايى ينج هزار ميكروليتر برسد. تركيب نهايى

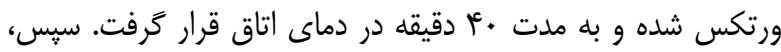
جذب محلول حاصله در طول موج هاب نانومتر اندازه گيرى شد.

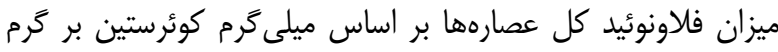

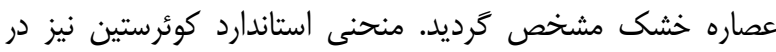

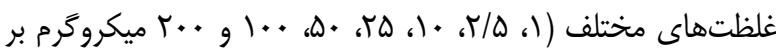

$$
\text { ميلى ليتر) تهبيه شد. }
$$

جهت سنجش ميزان فنل كل عصارههاى جوانه خام و پخته بروكلى از روش فولين-سيوكالتو' به شيوهى طيف سنجى استفاده شد. در ابتدا، ..1 ميكروليتر از هر يك از عصارهها با •ه ميكروليتر فولين سيوكالتو يك مولار مخلوط گرديد و سبس به آن هـ/ ميلى ليتر آب ديونيزه اضافه شد. آن گاه ..ب ميكروليتر كربنات سديم

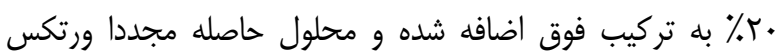

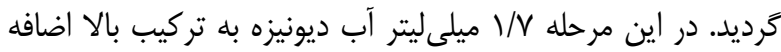

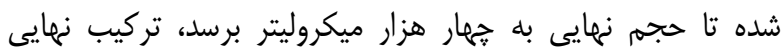
مجددا ورتكس شده و به مدت •9 دقيقه در شرايط تاريكى در دماى

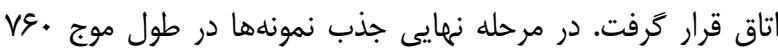

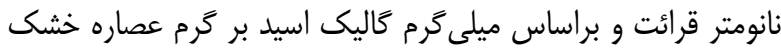
بيان گرديد. همجنين منحنى استاندارد كاليى اسيد در غلظتهاى

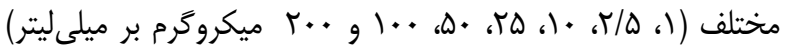

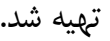

دست أمده به مدت عآ ساعت در دماى •V- درجه سانتيخراد منجمد و سيس توسط دستخاه خشك كن انجمادى خشك شد و تا زمان استفاده در دماى أ درجه سانتيخر اد نكَهدارى شد.

\section{تهيه عصاره جوانه يخته كلم بروكلى}

جهت تهيه عصاره جوانه يخته، •م كرم از جوانهاى بَ روزه كلم بروكلى درون يك كيسه زيڤ دار قابل انعطاف قرار كرفته و هواى داخل آن كاملا تخليه شد. سِّ كيس كيسه زيب دار داخل دستخاه

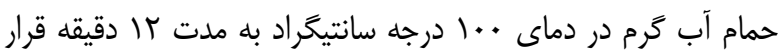

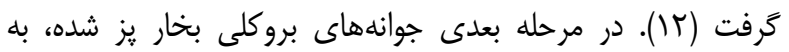

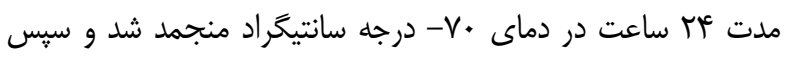

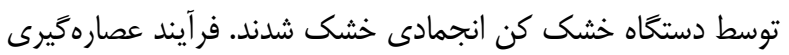
نيز طبق روش بالا انجام گرفت.

\section{بررسى ميزان سولفورافان موجود در عصاره جوانه خام

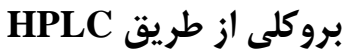
به منظور تعيين سولفورافان موجود در جوانههاى خام بروكلى، رولى محلول الكلى مشابه روش بيان شده در بخش قبل، تهيه و با روش

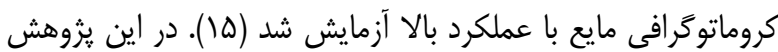

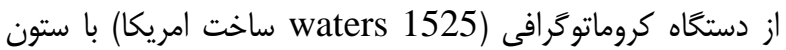
كروماتوگرافى فاز معكوس (Spherisorb C8 columns) به

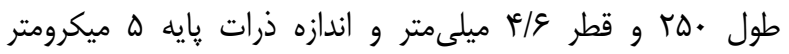
استفاده گرديد. به طور خلاصه • إميكروليتر از محلول الكلى عصاره

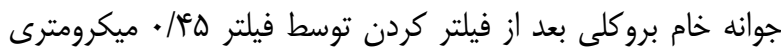

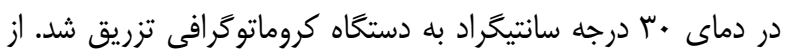

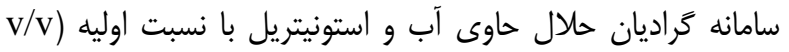

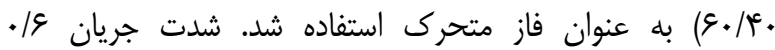
ميلىليتر بر دقيقه و آشكارساز در طول موج كبآ نانومتر تنظيه

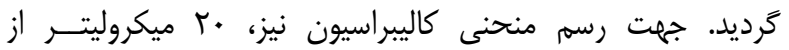
اسـتانداردهاى سولفورافان تهيــه شـــه در غلظتهاى ..1، .. آ،

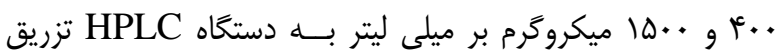

\footnotetext{
${ }^{1}$ Folin-Ciocalteu
} 
سانتيخراد براى مدت زمان זَr ساعت قرار كرفت. در اين يزوهش،

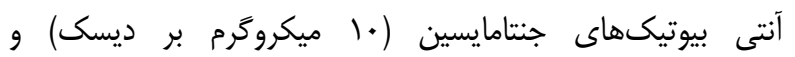

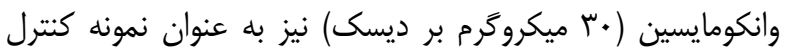
مثبت استفاده شد. قدرت ضدباكتريايى عصارهها بر اساس قطر هاله

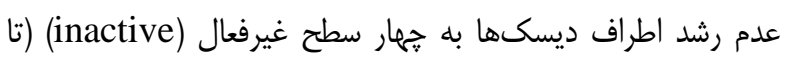

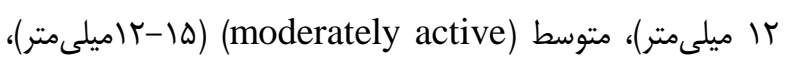

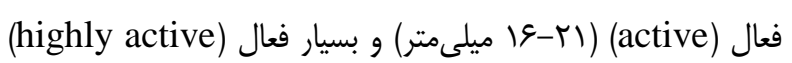
(بالاتر از \1 ميلىمتر) طبقه بندى شدند (1).

تعيين حداقل غلظت مهارى رشد (MIC) و حداقل غلظت كثندكى (MBC)

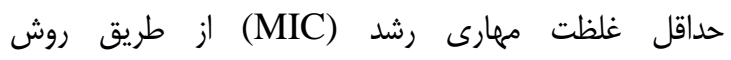
ماكرودايلوشن براث (Broth Macro dilution) طبق استاندارد تعيين كرديد. براى اين منظور، ابتدا (CLSI M07-A8)

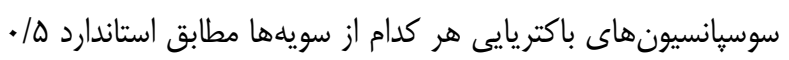
مك فارلند ( CFU/mL ^• (1) در محيط كشت نوترينت براث تمهيه

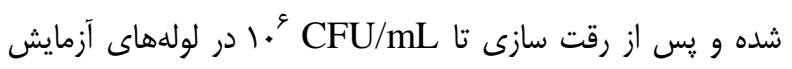

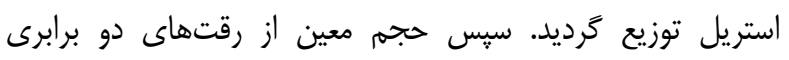

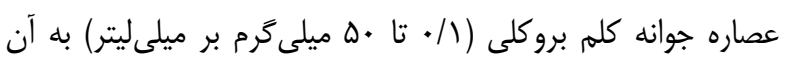

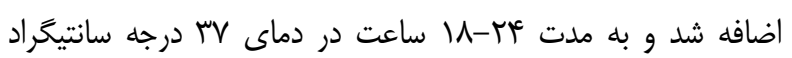

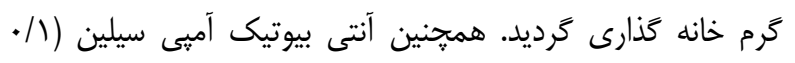

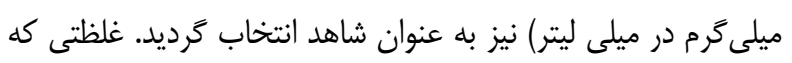

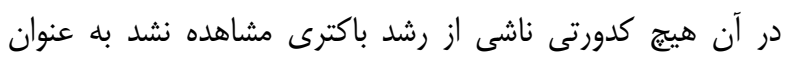

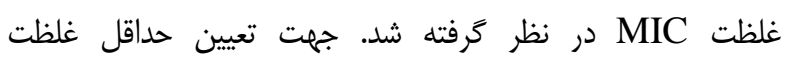
كشندگى (MBC) نيز مقدار •ه ميكروليتر از غلظتهاى فاقد كدورت، بر روى يليتهاى حاوى محيط كشت مولر هينتون آكار

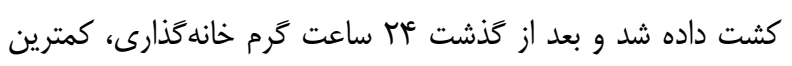

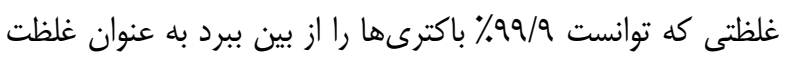

$$
\text { MBC }
$$

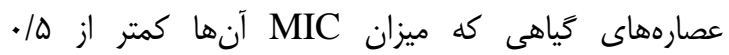
ميلى كرم در ميلىليتر است، فعاليت ضدميكروبى بالايى (

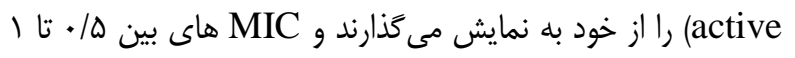

بررسى فعاليت آنتى اكسيدانى به روش جذب راديكال

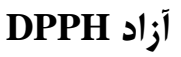

جهت سنجش فعاليت مهاركنندگى راديكال آزاد DPPH، يك راد

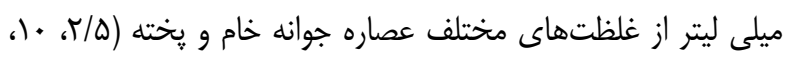

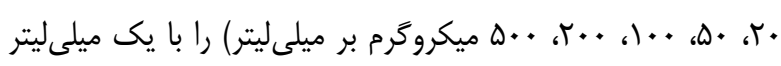

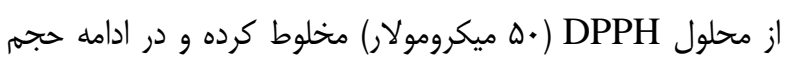

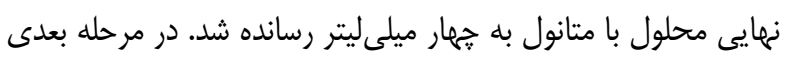

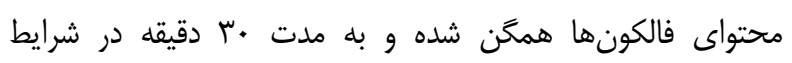

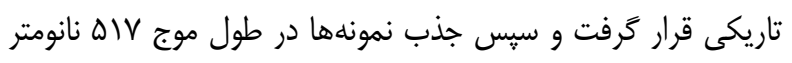

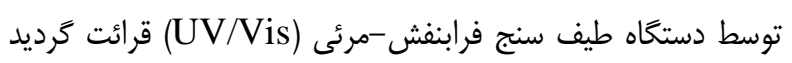

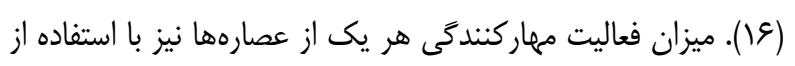

$$
\text { فرمول زير محاسبه شد: }
$$

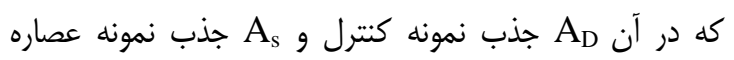

\section{بررسى فعاليت ضدباكتريايى عصارههاى جوانه خام و

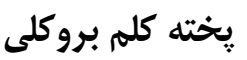
فعاليت ضدباكتريايى عصارهها با استفاده از روش انتشار

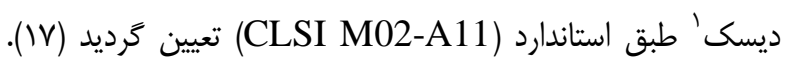

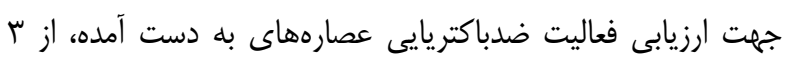

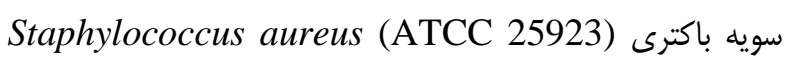
(PTCC 1399) ،Bacillus cereus (PTCC 1015)، Enterococcus و Mو Escherichia coli Listeria monocytogenes g faecalis خلاصه سوسيانسيونهاى باكتريايى رشد يافته درون محيط كشت نوترينت براث، بر روى محيط كشت مولر هينتون آَار (مرى آلمان)

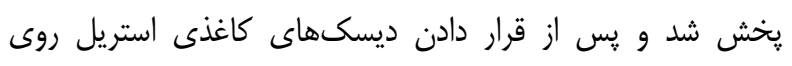

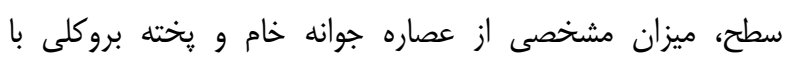

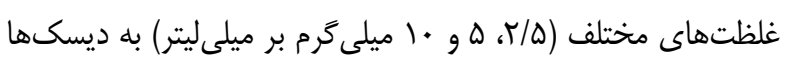

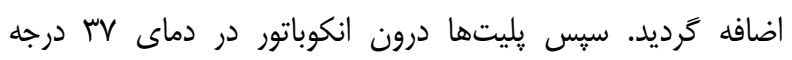

\footnotetext{
${ }^{1}$ Disk diffusion
} 
سولفورافان موجود در عصاره جوانه خام بروكلى، YAV/4 ميكروگرم بر ميلىليتر تعيين شد.

محتواى فنل و فلاونوئيد كل عصارههاى جوانه خام و

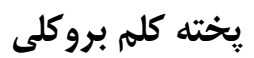

ميزان تركيبات فنلى و فلاونوئيد كل عصارههاى جوانه خام و ترو قخته كلم بروكلى مورد آزمون قرار كَرفت. نتايج نشان داد كه ميزان تركيبات فنلى كل عصارههاى جوانه خام و پخته كلم بروكلى به

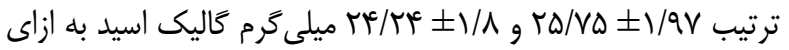
كرم ماده خشك و ميزان فلاونوئيد كل عصارههاى جوانه خام و يخته كلم بروكلى به ترتيب r./ ميلى گرم كوئرستين به ازاى گرم ماده خشك به درست به آمده است.

بررسى فعاليت آنتى اكسيدانى به روش جذب راديكال آزاد آنروسي

بررسى فعاليت آنتىاكسيدانى عصارههاى جوانه خام و پخته كلم بروكلى به روش جذب راديكال آزاد DPPH نشان داد كه خاصيت

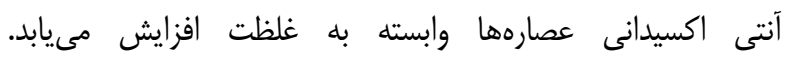
عصارههاى جوانه خام و زخته بروكلى فعاليت آنتىاكسيدانى جشمخيرى را از خود به نمايش كذاشتند، به طورى كه بيشترين مهار

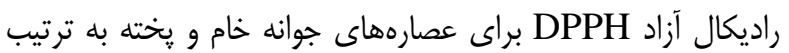

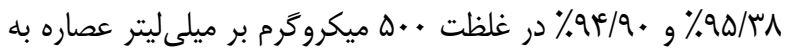
دست آمد. مقايسه فعاليت آنتىاكسيدانى عصارههاى جوانه خام و يخته كلم بروكلى در تصوير r آمده است.

فعاليت ضدباكتريايى عصارههاى جوانه خام و پخته كلم

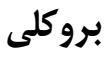

اثر ضـــدباكتريايى عصارههاى جوانه خام و وخته كلم بروكلى بر روى باكترىهاى گرم مثبت و گرم منفى مورد بررسى قرار گرَفت.

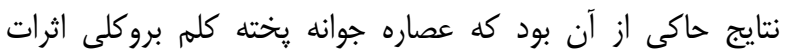

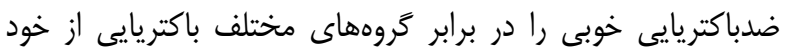
نشان داده است (جدول r-الف). در اين ميان، باكترىهاى گرم
ميلى همجنين MIC هاى بين ا تا م ميلى

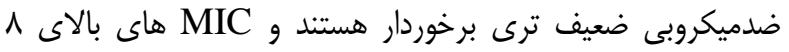
ميلى گرم در ميلىليتر نيز غيرفعال (inactive) در نظر كرفته مئه

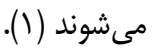

$$
\text { آناليز آمارى }
$$

جهت تحليل دادههاى خام بلدست آمده بنا به نياز از نرمافزارهاى SPSS 26 و 9 و 9 واستفاده شد. اختاف معنىدار توسط آناليز واريانس يك طرفه (ANOVA) از (از طريق آزمون تعقيبى خند دامنه دانكن مورد بررسى قرار كرفت. نتايج

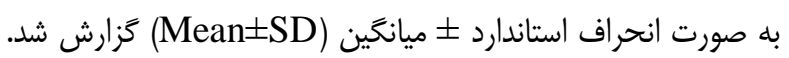

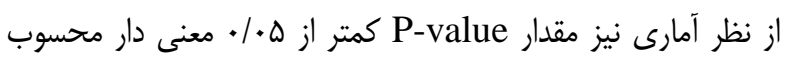

$$
\text { كرديد (ه) }
$$

مطالعه حاضر يس از تأييد كميته اخلاق دانشگاه با كد Ir.ausmt.rec.1398.11.33 انجام شد.

\section{يافته ها}

تعيين ميزان سولفورافان موجود در عصارهى جوانه خام

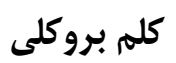

به منظور تعيين كيفى سولفورافان موجود در عصارهى جوانه

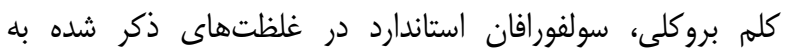

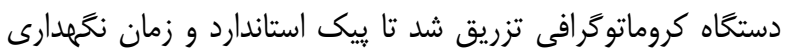
نمونه در ستون مشخص گردد، سيس عصاره جوانه بروكلى در دماى • ب درجه سانتيكراد به ستون كروماتوَّرافى تزريق گَرديد.

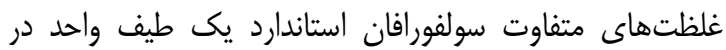

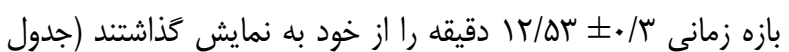

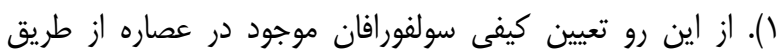

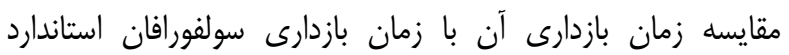
خالص انجام و توسط طيفهاى مشخصه بلهدست آمده از آشكارساز

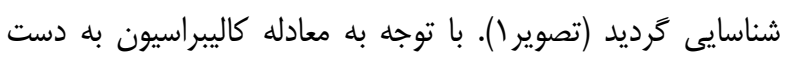

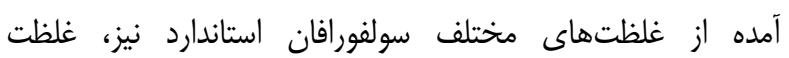


در اثر استفاده از فرايند حرارتى، اين خاصيت بروز مى كند.

\section{حداقل غلظت مهاركندكى رشد (MIC) و حداقل}

\section{غلظت كثندَّى (MBC)}

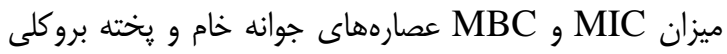
نيز در مقابل سويههاى باكتريايى ذكر شده مورد ارزيابى قرار گرَفت. بر اساس نتايج به دست آمده مشخص شد كه عصاره جوانه يخته

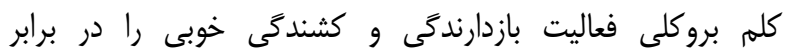

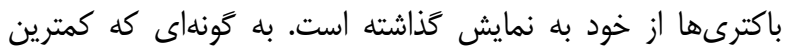

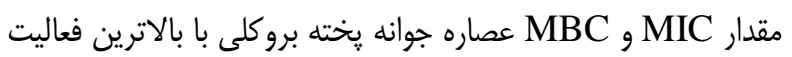

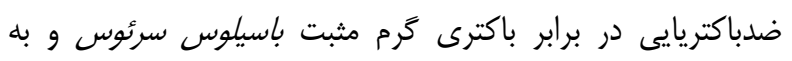

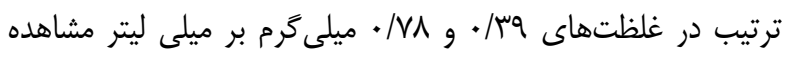

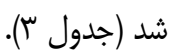

مثبت باسيلوس سرئوس و گرم منفى /شريشيا كلاى نســـبت به

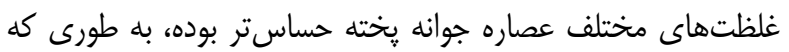

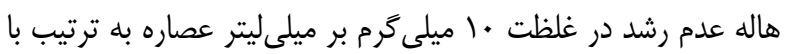

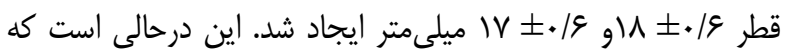

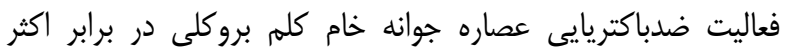

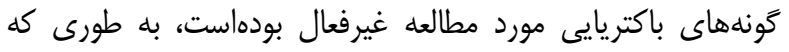

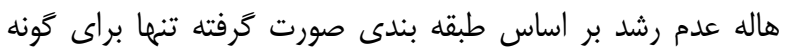
باسيلوس سرئوس در غلظت •ا ميلى گرم بر ميلىليتر و در سطح

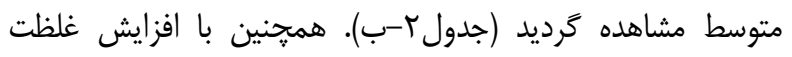

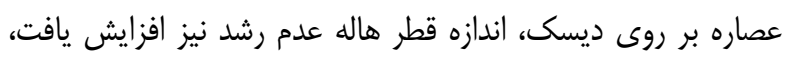
جنانجه در غلظت • إميلى گرم بر ميلى ليتر عصاره جوانه، بالاترين

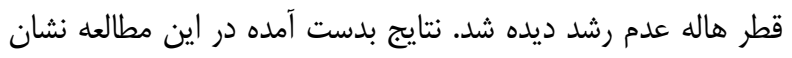
داد كه عصاره جوانه خام كلم بروكلى فعاليت ضدميكروبى ندارد؛ امّا

جدول ا - مقايسه زمان بازدارى و سطح زير يِيك غلظتهاى مختلف سولفورافان استاندارد با عصارهى جوانه خام كلم بروكلى

\begin{tabular}{|c|c|c|c|c|c|}
\hline \multirow[t]{2}{*}{ عصاره جوانه كلم بروكلى } & \multicolumn{4}{|c|}{ سولفورافان استاندارد خالص بر حسب ميكروترم بر ميلىليتر } & \\
\hline & $10 \cdots$ & e.. & $r \cdot$. & $1 .$. & \\
\hline $\mid r / r \mu r$ & $\mid r / V I V$ & $\mid r / \cdot \Lambda r$ & $\mid r / \Delta \Lambda$ & IT/VGT & زمان بازدارى (دقيقه) \\
\hline 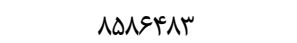 & $1099 M \wedge \Delta \%$ & crq... . & TEIVEFT & MART.r & مساحت ييى \\
\hline
\end{tabular}

جدول ץ-الف: قطر هاله عدم رشد باكترىها در مقابل غلظتهاى مختلف عصاره جوانه پِخته كلم بروكلى و آنتى بيوتيك (بر حسب ميلىمتر)

\begin{tabular}{|c|c|c|c|c|c|}
\hline \multirow{2}{*}{ نوع آنتى بيوتيك } & \multirow{2}{*}{ آنتى بيوتيك } & \multicolumn{3}{|c|}{ غلظت عصارهها بر حسب ميلى ترم بر ميلى ليتر } & \multirow{2}{*}{ باكترى } \\
\hline & & $1+$ & $\Delta$ & $r / Q$ & \\
\hline جتنامايسين (1·pg/disc) & $\aleph \pm . /$ & $\mid V \pm \cdot 19^{b}$ & $10 \pm \cdot / \digamma^{c}$ & $\pi \pm \cdot / r^{d}$ & E.coli (PTCC 1399) \\
\hline 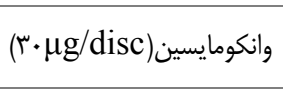 & $r \cdot \pm \cdot / \cdot$ & $\mid V \pm \cdot / r^{b}$ & $10 \pm \cdot / 9^{c}$ & $11 \pm .19^{\mathrm{de}}$ & $\begin{array}{l}\text { Staphylococcus aureus } \\
\text { (ATCC 25923) }\end{array}$ \\
\hline وانكومايسين & $r \cdot \pm \cdot / \cdot$ & $11 \pm \cdot / 9^{a}$ & $10 \pm \cdot / 9^{c}$ & $r \pm \cdot / r^{d}$ & $\begin{array}{c}\text { Bacillus cereus (PTCC } \\
1015)\end{array}$ \\
\hline وانكومايسين & $r \cdot \pm \cdot / \cdot$ & $10 \pm \cdot / V^{c}$ & $\pi \pm . / 9^{d}$ & $1 \cdot \pm \cdot / 9^{\mathrm{ef}}$ & $\begin{array}{c}\text { Enterococcus faecalis } \\
\text { (بالينى) }\end{array}$ \\
\hline وانكومايسين & $\aleph \pm \pm$. & $\mid f \pm \cdot / r^{c}$ & $11 \pm \cdot / \digamma^{\mathrm{de}}$ & $q \pm \cdot / r^{f}$ & $\begin{array}{c}\text { Listeria monocytogenes } \\
\text { (بالينى) }\end{array}$ \\
\hline
\end{tabular}

* ميانكينهايى كه حداقل داراى يك حرف مشابه هستند، بر مبناى آزمون جند دامنهى دانكن در سطح ه./ تفاوت معنىارى ندارند. 
جدول ז-ب: قطر هاله عدم رشد باكترىها در مقابل غلظتهاى مختلف عصاره جوانه خام كلم بروكلى و آنتى بيوتيك (بر حسب ميلىمتر)

\begin{tabular}{|c|c|c|c|c|c|}
\hline \multirow{2}{*}{ نوع آنتى بيوتيكى } & \multirow{2}{*}{ آنتى بيوتيك } & \multicolumn{3}{|c|}{ غلظت عصارهها بر حسب ميلى ترم بر ميلى ليتر } & \multirow{2}{*}{ 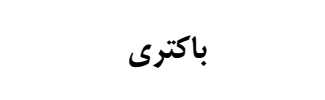 } \\
\hline & & $1+$ & $\Delta$ & $r / 0$ & \\
\hline جنتامايسين(1·pg/disc) & $\longleftrightarrow \pm \cdot /$ & $1 \cdot \pm \cdot 19^{b}$ & $\Lambda \pm \cdot / r^{\mathrm{d}}$ & $v \pm \cdot / r^{\mathrm{e}}$ & E.coli (PTCC 1399) \\
\hline 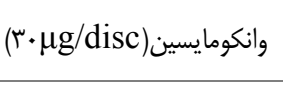 & $r \cdot \pm \cdot / \cdot$ & $V \pm \cdot / r^{\mathrm{e}}$ & $v \pm \cdot / r^{\mathrm{e}}$ & $\cdot \pm \cdot / .^{\mathrm{f}}$ & $\begin{array}{l}\text { Staphylococcus aureus } \\
\text { (ATCC 25923) }\end{array}$ \\
\hline وانكومايسين & $r \cdot \pm \cdot / \cdot$ & $\pi \pm . / v^{a}$ & $q \pm \cdot / r^{c}$ & $V \pm \cdot / f^{\text {de }}$ & $\begin{array}{c}\text { Bacillus cereus (PTCC } \\
\text { 1015) }\end{array}$ \\
\hline وانكومايسين & $r \cdot \pm \cdot / \cdot$ & $\cdot \pm \cdot / \cdot^{\mathrm{f}}$ & $\cdot \pm \cdot / \cdot^{\mathrm{f}}$ & $\cdot \pm \cdot / \cdot{ }^{\mathrm{f}}$ & Enterococcus faecalis \\
\hline وانكومايسين & $\aleph \pm \cdot /$ & $\cdot \pm \cdot / \cdot{ }^{\mathrm{f}}$ & $\cdot \pm \cdot / \cdot^{\mathrm{f}}$ & $\cdot \pm \cdot / \cdot{ }^{\mathrm{f}}$ & Listeria monocytogenes \\
\hline
\end{tabular}

* ميانكينهايى كه حداقل داراى يك حرف مشابه هستند، بر مبناى آزمون حند دامنهى دانكن در سطح هـ/. تفاوت معنى دارى ندارند.

جدول سـ- حداقل غلظت بازدارندَّى و كثندَّى (بر حسب ميلى تَرم در ميلى ليتر)

\begin{tabular}{|c|c|c|c|c|}
\hline \multicolumn{2}{|c|}{ عصاره جوانه خام كلم بروكلى } & \multicolumn{2}{|c|}{ عصاره جوانه پِخته كلم بروكلى } & \multirow[t]{2}{*}{ 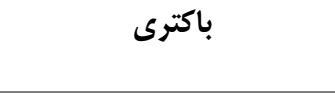 } \\
\hline MBC & MIC & MBC & MIC & \\
\hline$I r / \Delta^{f}$ & $s / r \Delta^{e}$ & $1 / \Delta S^{c}$ & $\cdot / \mathrm{vN}^{\mathrm{b}}$ & E.coli (PTCC 1399) \\
\hline$r \omega^{g}$ & $I r / \Delta^{\mathrm{f}}$ & $1 / \Delta F^{c}$ & $\cdot / \mathrm{vN}^{\mathrm{b}}$ & $\begin{array}{l}\text { Staphylococcus aureus } \\
\text { (ATCC 25923) }\end{array}$ \\
\hline$I r / \Delta^{f}$ & $s / r \omega^{e}$ & $\cdot / \mathrm{vA}^{\mathrm{b}}$ &.$/ q^{a}$ & $\begin{array}{c}\text { Bacillus cereus (PTCC } \\
1015)\end{array}$ \\
\hline 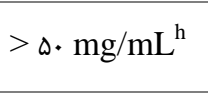 & $r \omega^{g}$ & $r / / r^{d}$ & $1 / \Delta \varphi^{c}$ & $\begin{array}{c}\text { Enterococcus faecalis } \\
\text { (بالينى) }\end{array}$ \\
\hline$>\Delta \cdot \mathrm{mg} / \mathrm{mL}^{\mathrm{h}}$ & $>\Delta \cdot \mathrm{mg} / \mathrm{mL}^{\mathrm{h}}$ & $s / r \omega^{\mathrm{e}}$ & $r / / \mu^{d}$ & $\begin{array}{c}\text { Listeria monocytogenes } \\
\text { (بالينى) }\end{array}$ \\
\hline
\end{tabular}

* ميانكَينهايى كه حداقل داراى يك حرف مشابه هستند، بر مبناى آزمون حند دامنهى دانكن در سطح هـ/• تفاوت معنى دارى ندارند.

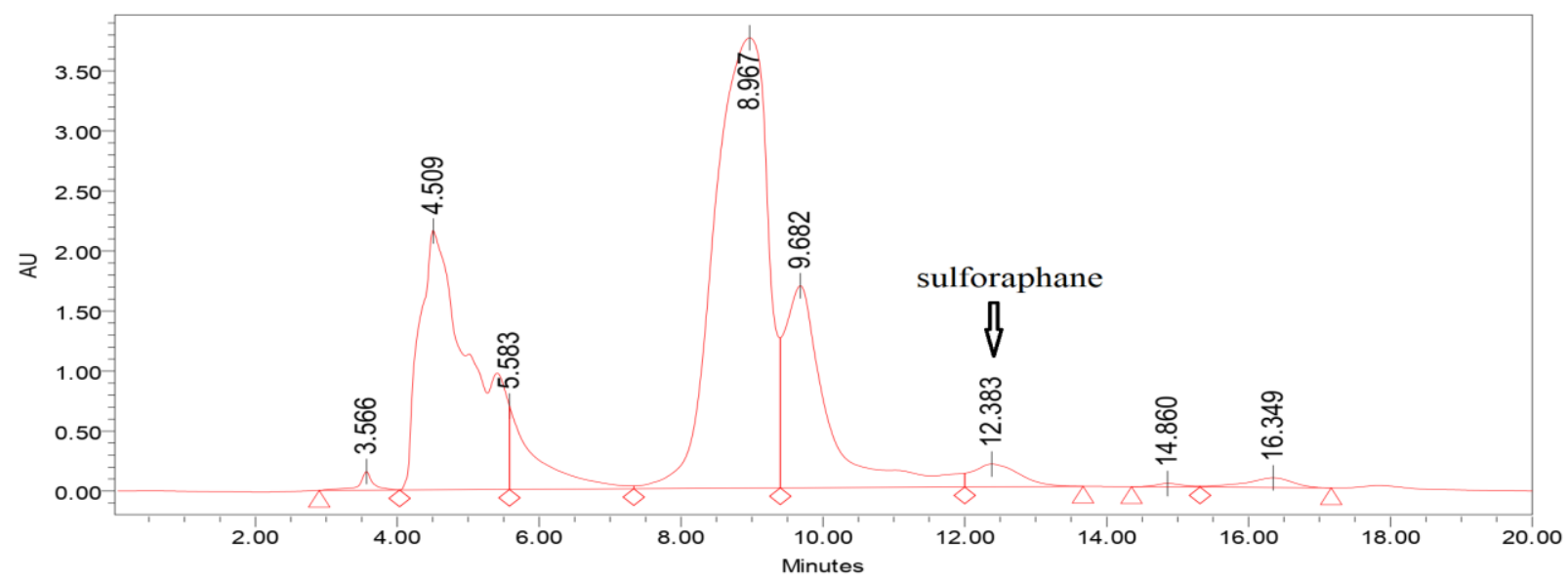

تصوير ا - كروماتوترام عصاره جوانه خام كلم بروكلى 


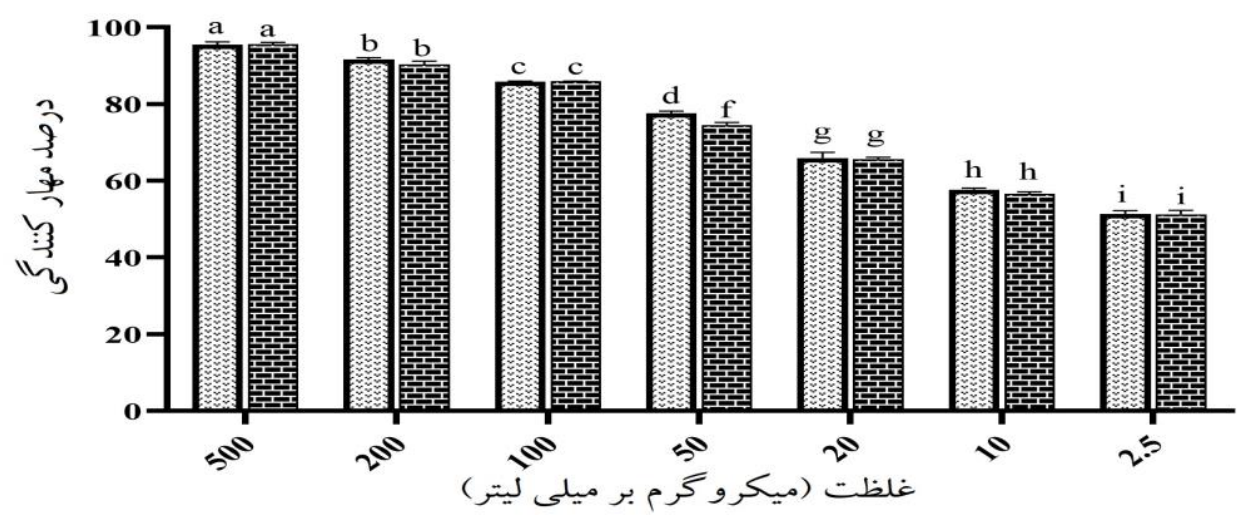

نمودار ر ا - ميزان فعاليت آنتى اكسيدانى عصارههاى جوانه خام و يخته كلم بروكلى (ميانكينهايى كه داراى حروف مشابه هستند، بر مبناى آزمون جند دامنهى دانكن در سطح هـ/ ت تفاوت معنى دارى ندارند)

تركيبات گردد (با). بنابراين انتخاب روش يخت و يز مناسب مىتواند مهمترين عامل در حفظ تركيبات زيستى موجود در كله

$$
\text { بروكلى تلقى شود. }
$$

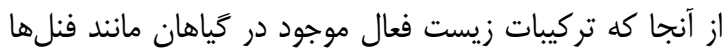

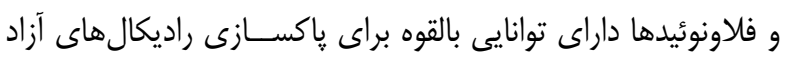

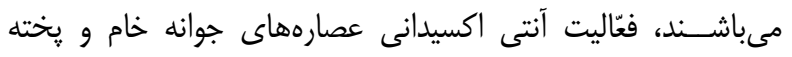

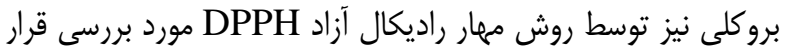

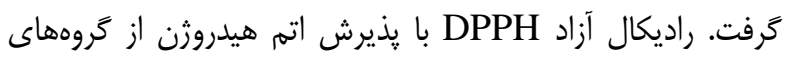

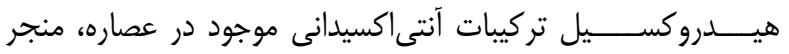
به كاهش محتواى DPPH و تغيير رنغ محلول واكنش از بنفش انش

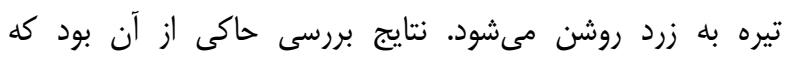

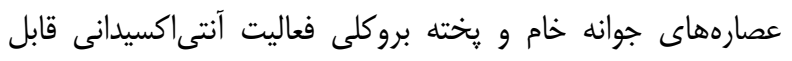
توجهى در غلظتهاى مختلف از خود به نمايش كذاشتند و فعاليت

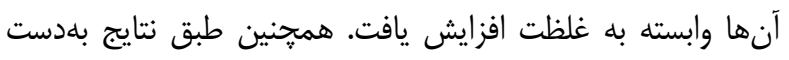

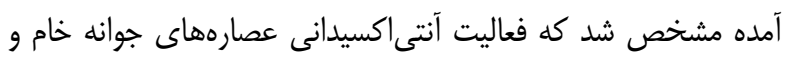

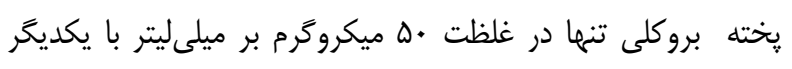

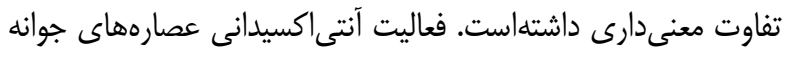

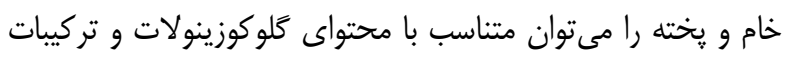

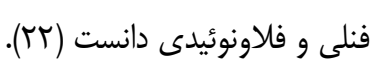

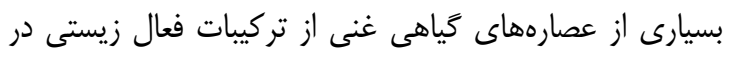

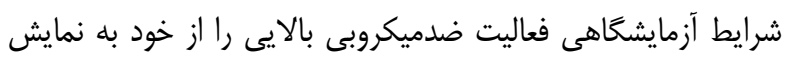

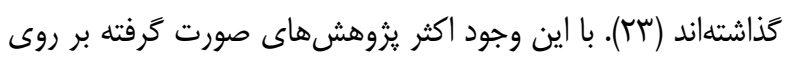
فعاليتهاى بيولوزيكى كلم بروكلى، متمركز بر خواص آنس آنتى

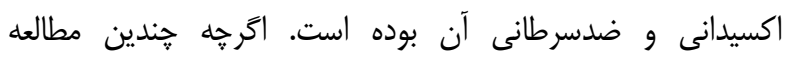

در اين يزوهش فعاليت تركيبات زيست فعال موجود در

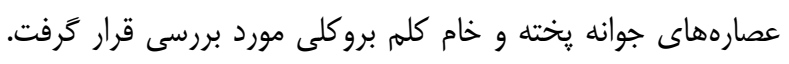

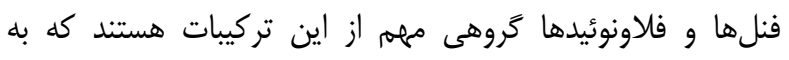

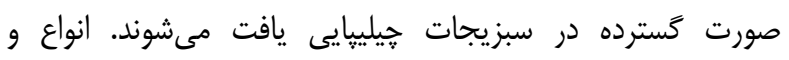

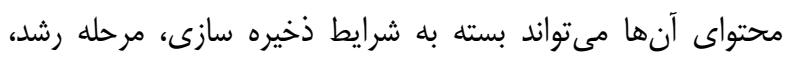

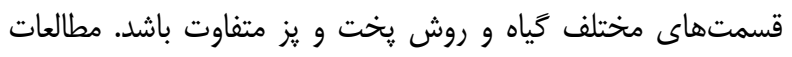

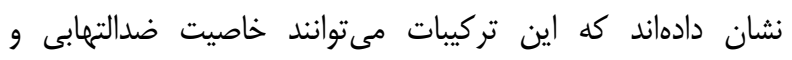

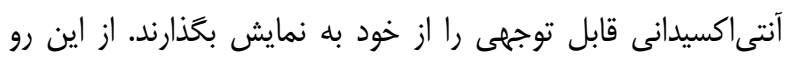

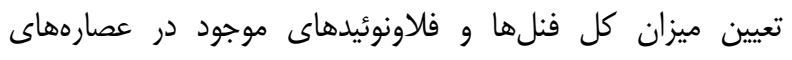
جوانهى خام و يخته كلم بروكلى امرى ضرورى به به حساب مئ آيد

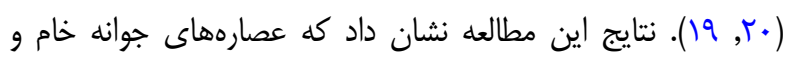

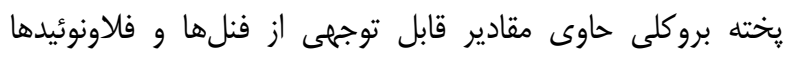

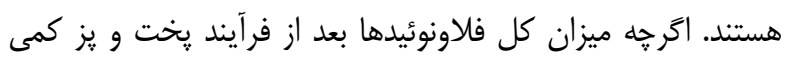

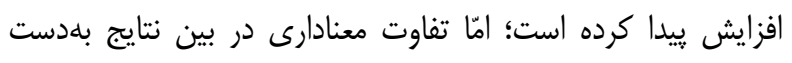

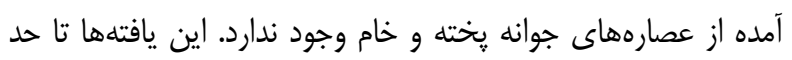

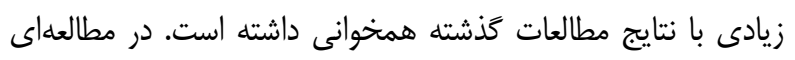

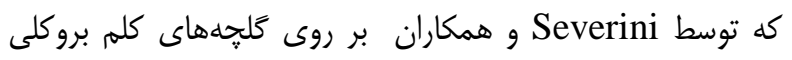
صورت كرفت مشخص شد كه ميزان كل تركيبات فنلى يس از

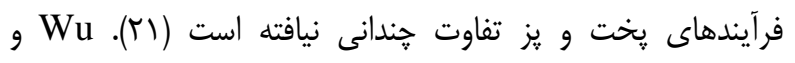

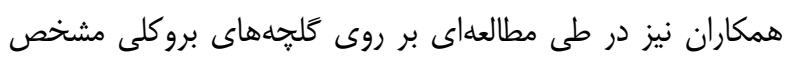

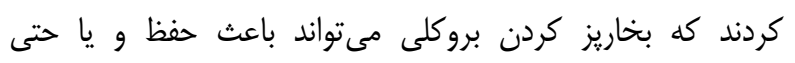

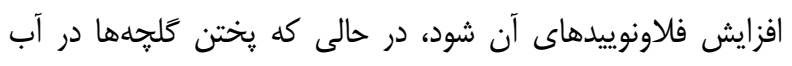

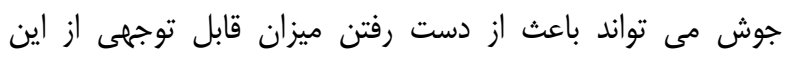


كرم منفى به استثناى گَونه باسيلوس سرئوس، در برابر عصاره جوانه

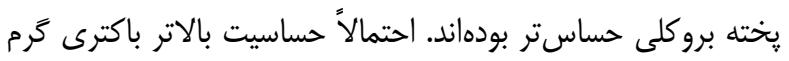

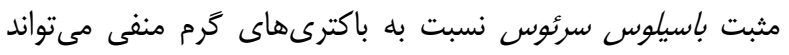

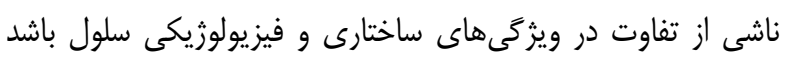

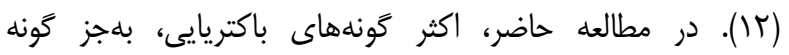
باسيلوس سرئوس، در برابر عصاره جوانه خام بروكلى كاملا مقاوم بودهاند. احتمال مىرود كه در عصاره جوانه يخته به علت استفاده از

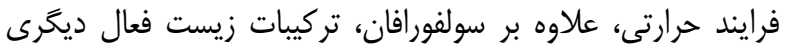

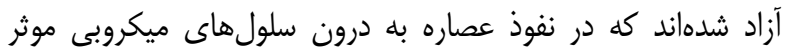

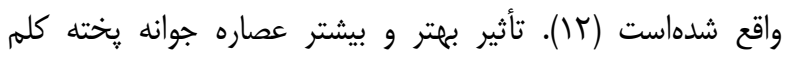

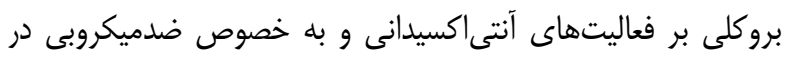

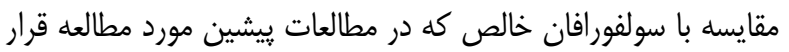

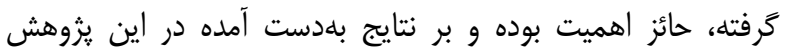

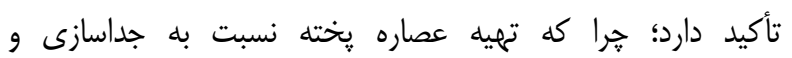
خالصسازى سولفورافان مقرون به صرفهتر و راحتتر است؛ بنابراين

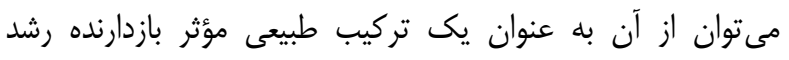

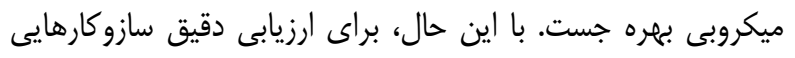

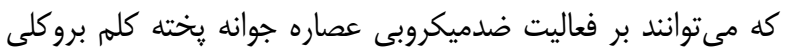

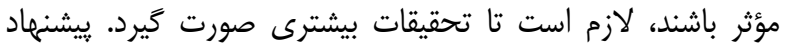

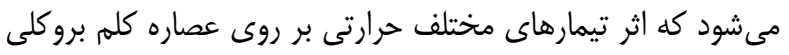

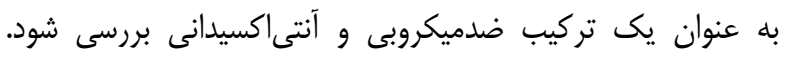

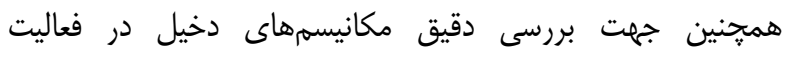

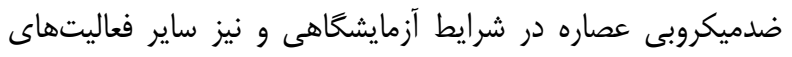

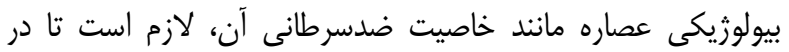

$$
\text { آينده تحقيقات بيشترى صورت كيرد. }
$$

\section{نتيجه}

در اين يزوهش، عصارههاى جوانه يخته و خام كلم بروكلى

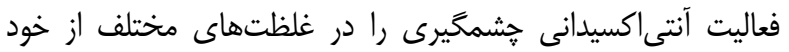

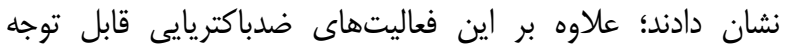

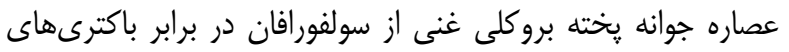

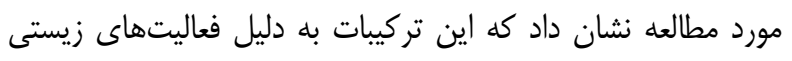

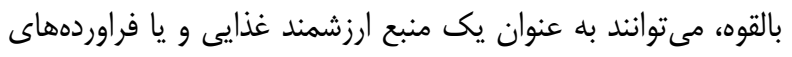

$$
\text { بهداشتى و درمانى درنظر كرفته شوند. }
$$

فعاليتهاى ضدميكروبى كلم بروكلى بر روى عوامل بيمارى زا را إ

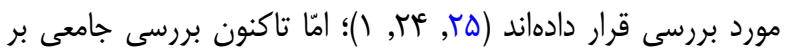

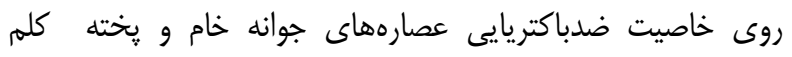

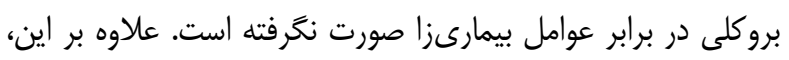

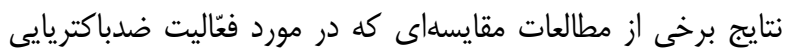

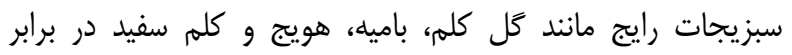

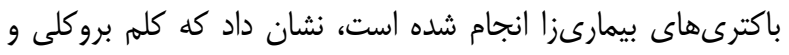

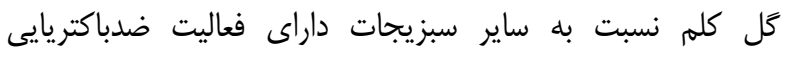
بالاترى هستند (سٓ). مطالعه حاضر نيز نشان داد كه عصارهى جوانه

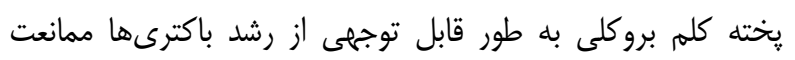

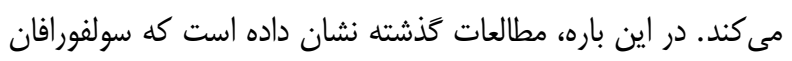

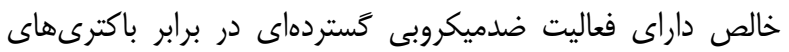

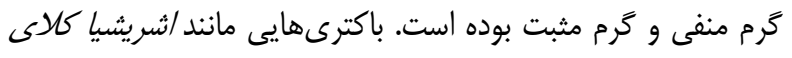

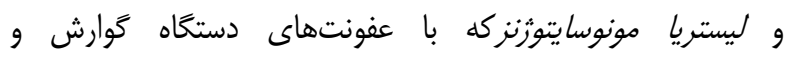

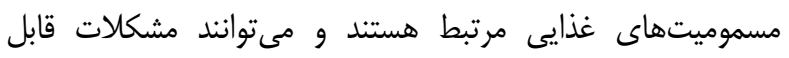
توجهى براى انسان ايجاد كنند (VV, عائ).

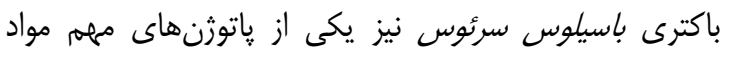

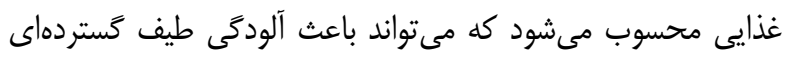

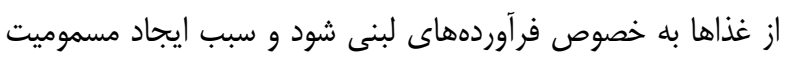

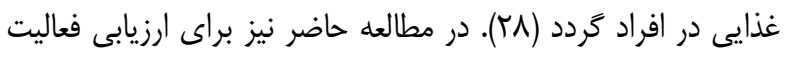

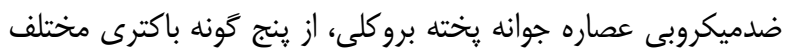

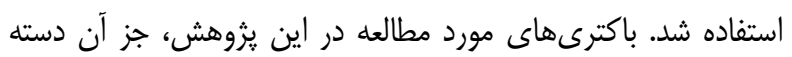

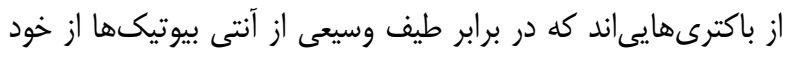
مقاومت نشان مى دهند؛ لذا يافتن تركيبات طبيعى مناسب با فا فعاليت

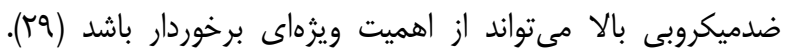

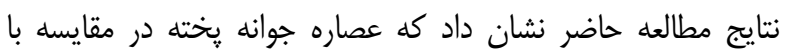

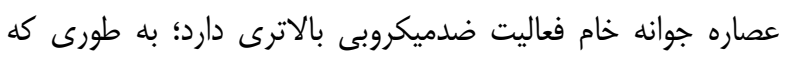

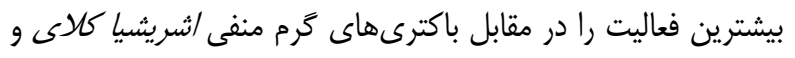

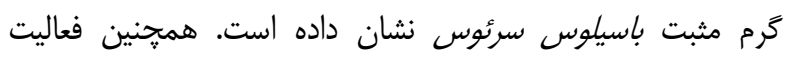

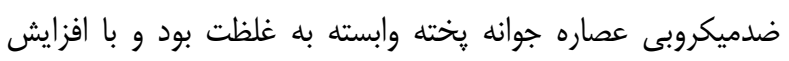
غلظت عصاره بر روى ديسكها، قطر هاله عدم رشد نيز افزايش

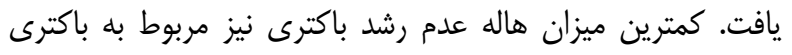

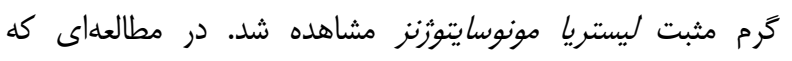
Abukhabta كلم بروكلى انجام دادند مشخص شد كه به طور كلى باكترى بهاى 
1- Le TN, Luong HQ, Li HP, Chiu CH, Hsieh PC. Broccoli (Brassica oleracea L. var. italica) sprouts as the potential food source for bioactive properties: a comprehensive study on in vitro disease models. Foods. 2019; 8(11): 532. DOI: 10.3390/foods 8110532

2- Subedi L, Cho K, Park YU, Choi HJ, Kim SY. Sulforaphane-enriched broccoli sprouts pretreated by pulsed electric fields reduces neuroinflammation and ameliorates scopolamine-induced amnesia in mouse brain through its antioxidant ability via Nrf2-HO-1 activation. Oxid Med Cell Longev. 2019; 2019. DOI: 10.1155/2019/3549274

3- Vale AP, Santos J, Melia N, Peixoto V, Brito NV, Oliveira MB. Phytochemical composition and antimicrobial properties of four varieties of Brassica oleracea sprouts. Food Control. 2015; 55: 248-56. DOI: 10.1016/j.foodcont.2015.01.051

4- Cartea ME, Francisco M, Soengas P, Velasco P. Phenolic compounds in Brassica vegetables. Molecules. 2011; 16(1): 251-80. DOI: 10.3390/molecules16010251

5- Palliyaguru DL, Yuan JM, Kensler TW, Fahey JW. Isothiocyanates: Translating the power of plants to people. Mol Nutr Food Res. 2018; 62(18): 1700965. DOI: 10.1002/mnfr.201700965

6- Fahey JW, Wade KL, Stephenson KK, Panjwani AA, Liu H, Cornblatt G, et al. Bioavailability of sulforaphane following ingestion of glucoraphanin-rich broccoli sprout and seed extracts with active myrosinase: A pilot study of the effects of proton pump inhibitor administration. Nutrients. 2019; 11(7): 1489. DOI: 10.3390/nu11071489

7- Aires A, Mota VR, Saavedra MJ, Rosa EA, Bennett RN. The antimicrobial effects of glucosinolates and their respective enzymatic hydrolysis products on bacteria isolated from the human intestinal tract. J Appl Microbiol. 2009; 106(6): 2086-95. DOI: 10.1111/j.1365-2672.2009.04180.x

8- Juge N, Mithen RF, Traka M. Molecular basis for chemoprevention by sulforaphane: a comprehensive review. Cell Mol Life Sci. 2007; 64(9): 1105-27. DOI: 10.1007/s00018-007-6484-5

9- Moreira-Rodríguez M, Nair V, Benavides J, Cisneros-Zevallos L, Jacobo-Velázquez DA. UVA, UVB light, and methyl jasmonate, alone or combined, redirect the biosynthesis of glucosinolates, phenolics, carotenoids, and chlorophylls in broccoli sprouts. Int J Mol Sci. 2017; 18(11): 2330. DOI: 10.3390/ijms18112330

10- Baenas N, Gómez-Jodar I, Moreno DA, García-Viguera C, Periago PM. Broccoli and radish sprouts are safe and rich in bioactive phytochemicals. Postharvest Biol Technol. 2017 1; 127: 60-7. DOI: $10.1016 /$ j.postharvbio.2017.01.010

11- Castillejo N, Martínez-Zamora L, Gómez PA, Pennisi G, Crepaldi A, Fernández JA, et al. Postharvest LED lighting: effect of $r$ ed, $b$ lue and $\mathrm{f}$ ar $\mathrm{r}$ ed on quality of minimally processed broccoli sprouts. J Sci Food Agric. 2021; 101(1): 44-53. DOI: 10.1002/jsfa. 10820

12- Abukhabta S, Ghawi SK, Karatzas KA, Charalampopoulos D, McDougall G, Allwood JW, et al. Sulforaphaneenriched extracts from glucoraphanin-rich broccoli exert antimicrobial activity against gut pathogens in vitro and innovative cooking methods increase in vivo intestinal delivery of sulforaphane. Eur J Nutr. 2021; 60(3): 12631276. . DOI: $10.1007 / \mathrm{s} 00394-020-02322-0$

13- Wu X, Zhao Y, Haytowitz DB, Chen P, Pehrsson PR. Effects of domestic cooking on flavonoids in broccoli and calculation of retention factors. Heliyon. 2019; 5(3): e01310. DOI: 10.1016/j.heliyon.2019.e01310 
14- Sadeghi AR, Pourahmad R, Mokhtare M. Enrichment of probiotic yogurt with broccoli sprout extract and its effect on Helicobacter pylori. Appl Food Biotechnol. 2017; 4(1): 53-7 DOI: 10.22037/afb.v4i1.13828

15- Ke YY, Shyu YT, Wu SJ. Evaluating the Anti-Inflammatory and Antioxidant Effects of Broccoli Treated with High Hydrostatic Pressure in Cell Models. Foods. 2021; 10(1): 167. DOI: 10.3390/foods10010167

16- Shabaani M, Rahaiee S, Zare M. Evaluation of Antibacterial and Antioxidant Activities of Biosynthesized Zinc oxide Nanoparticles using Aqueous Extract of Eriobotrya Japonica Seeds. J Ilam Univ Med Sci. 2020; 28(5): 21-32. DOI: $10.29252 /$ sjimu.28.5.21

17- CLSI, Performance Standards for Antimicrobial Disk Susceptibility Tests, Approved Standard, 7th ed., CLSI document M02-A11. Clinical and Laboratory Standards Institute, 950 West Valley Road, Suite 2500, Wayne, Pennsylvania 19087, USA, 2012. Link

18- CLSI. Methods for Dilution Antimicrobial Susceptibility Tests for Bacteria That Grow Aerobically. $11^{\text {th }}$ ed. CLSI document M07. Wayne, PA: Clinical and Laboratory Standards Institute; 2018. Link

19- Paśko P, Tyszka-Czochara M, Galanty A, Gdula-Argasińska J, Żmudzki P, Bartoń H, et al. Comparative study of predominant phytochemical compounds and proapoptotic potential of broccoli sprouts and florets. Plant Foods Hum Nutr. 2018; 73(2): 95-100. DOI: 10.1007/s11130-018-0665-2

20- de la Fuente B, López-García G, Máñez V, Alegría A, Barberá R, Cilla A. Evaluation of the bioaccessibility of antioxidant bioactive compounds and minerals of four genotypes of Brassicaceae microgreens. Foods. 2019; 8(7): 250. DOI: $10.3390 /$ foods 8070250

21- Severini C, Giuliani R, De Filippis A, Derossi A, De Pilli T. Influence of different blanching methods on colour, ascorbic acid and phenolics content of broccoli. J Food Sci Technol. 2016 1; 53(1):501-10. DOI: 10.1007/s13197015-1878-0

22- Hwang ES. Effect of cooking method on antioxidant compound contents in cauliflower. Prev Nutr Food Sci.. 2019; 24(2): 210. DOI: 10.3746/pnf.2019.24.2.210

23- Hinds L, Kenny O, Hossain MB, Walsh D, Sheehy E, Evans P, et al. Evaluating the antibacterial properties of polyacetylene and glucosinolate compounds with further identification of their presence within various carrot (Daucus carota) and Broccoli (Brassica oleracea) cultivars using high-performance liquid chromatography with a diode array detector and ultra performance liquid chromatography-tandem mass spectrometry analyses. J Agric Food Chem. 2017; 65(33):7186-91. DOI: 10.1021/acs.jafc.7b02029

24- Pacheco-Cano RD, Salcedo-Hernández R, López-Meza JE, Bideshi DK, Barboza-Corona JE. Antimicrobial activity of broccoli (Brassica oleracea var. italica) cultivar Avenger against pathogenic bacteria, phytopathogenic filamentous fungi and yeast. J Appl Microbiol. 2018; 124(1):126-35. DOI: 10.1111/jam.13629

25- Sanz-Puig M, Pina-Pérez MC, Criado MN, Rodrigo D, Martínez-López A. Antimicrobial potential of cauliflower, broccoli, and okara byproducts against foodborne bacteria. Foodborne Pathog Dis. 2015 1; 12(1): 39-46. DOI: 10.1089/fpd.2014.1801

26- Saavedra MJ, Dias CS, Martinez-Murcia A, Bennett RN, Aires A, Rosa EA. Antibacterial effects of glucosinolatederived hydrolysis products against enterobacteriaceae and enterococci isolated from pig ileum segments. Foodborne Pathog Dis. 2012; 9(4): 338-45. DOI: 10.1089/fpd.2011.1035

27- Nowicki D, Rodzik O, Herman-Antosiewicz A, Szalewska-Pałasz A. Isothiocyanates as effective agents against enterohemorrhagic Escherichia coli: insight to the mode of action. Sci Rep. 2016; 6(1): 1-2. DOI: $10.1038 /$ srep22263

28- Le Lay J, Bahloul H, Sérino S, Jobin M, Schmitt P. Reducing activity, glucose metabolism and acid tolerance response of Bacillus cereus grown at various $\mathrm{pH}$ and oxydo-reduction potential levels. Food Microbiol. 2015; 46: 314-21. DOI: 10.1016/j.fm.2014.07.007

29- Adzitey F, Ekli R, Abu A. Prevalence and antibiotic susceptibility of Staphylococcus aureus isolated from raw and grilled beef in Nyankpala community in the Northern Region of Ghana. Cogent food agric. 2019; 5(1): 1671115. DOI: $10.1080 / 23311932.2019 .1671115$ 